\title{
Food partitioning between breeding White-tailed Kites (Elanus leucurus; Aves; Accipitridae) and Barn Owls (Tyto alba; Aves; Tytonidae) in southern Brazil
}

\author{
Scheibler, DR. (in memoriam) \\ Departamento de Zoologia, Universidade Estadual Paulista - UNESP, \\ CP 199, Av. 24A, 1515, CEP 13506-900, Rio Claro, SP, Brazil
}

Received February 21, 2005 - Accepted August 8, 2005 - Distributed February 28, 2007

(With 1 figure)

\begin{abstract}
I examined the diet of breeding White-tailed Kites (Elanus leucurus; Aves; Accipitridae) and Barn Owls (Tyto alba; Aves; Tytonidae) in an agrarian area of southern Brazil by analyzing regurgitated prey remains. The objective was to evaluate how these raptors, which differ markedly in their hunting activity periods (owls are nocturnal and kites diurnal), share their mammalian food component. 2,087 prey consumed by Barn Owls and 1,276 by White-tailed Kites were identified. They presented a high overlap of food-niches (Pianka's index was 0.98). Based on the daily activity period of their main small mammal prey, a lower overlap would be expected. The crepuscular/nocturnal Mus musculus was the main prey for the diet of breeding Barn Owls (81\%) and White-tailed Kites (63\%). This small exotic rodent provided $63 \%$ of the small mammal biomass ingested by owls and $44 \%$ by kites. Larger native small mammals were also considered important for the diet of kites, mainly because of their biomass contribution. Although these raptors differ markedly in their hunting activity periods, Barn Owls and White-tailed Kites are very similar predators in southern Brazil, overlapping their diets.
\end{abstract}

Keywords: breeding diet, small mammal prey, Elanus leucurus, Tyto alba, Brazil.

\section{Partilha de alimento entre o gavião-peneira (Elanus leucurus; Aves; Accipitridae) e a coruja suindara (Tyto alba; Aves; Tytonidae) durante a reprodução no sul do Brasil}

\begin{abstract}
Resumo
Examinaram-se as dietas do gavião-peneira (Elanus leucurus; Aves; Accipitridae) e da coruja suindara (Tyto alba; Aves; Tytonidae) em atividade reprodutiva numa área agrícola no Sul do Brasil, analisando restos de presas regurgitadas. O objetivo foi avaliar como estes predadores que diferem marcadamente quanto aos seus períodos de atividade de caça (a coruja é noturna e o gavião diurno) partilham seu componente alimentar de pequenos mamíferos. Identificaram-se 2087 presas consumidas pela suindara e 1276 pelo gavião-peneira. Eles apresentaram uma alta sobreposição de seus nichos alimentares (índice de Pianka de 0,98). Com base no período diário de atividade de suas principais presas de pequenos mamíferos, uma sobreposição menor seria esperada. O roedor crepuscular/noturno Mus musculus foi a principal presa para a dieta da suindara $(81 \%)$ e do gavião-peneira $(63 \%)$. Este pequeno roedor exótico forneceu $63 \%$ da biomassa de pequenos mamíferos ingerida pela coruja e $44 \%$ pelo gavião. Espécies maiores de pequenos mamíferos nativos também foram importantes para a dieta do gavião-peneira, principalmente devido às suas contribuições de biomassa. Embora haja diferenças marcantes quanto aos seus períodos de atividade de caça, a suindara e o gavião-peneira são predadores muito semelhantes no Sul do Brasil, sobrepondo amplamente suas dietas.
\end{abstract}

Palavras-chave: dieta reprodutiva, presas de pequenos mamíferos, Elanus leucurus, Tyto alba, Brasil.

\section{Introduction}

The White-tailed Kite (Elanus leucurus; Aves; Accipitridae) is a small raptor that inhabits mainly lowlands in the western and southern United States, Mexico, Central and South America (Dunk, 1995). It restricts hunting to open and moderately open environments such as grasslands, marshes, and agricultural areas (Waian and Stendell, 1970; Schlatter et al., 1980; Jaksić et al., 1987). This kite is considered a small mammal specialist, preying mainly on rodents (Mendelsohn and Jaksić, 1989; Dunk, 1995).

The Barn Owl (Tyto alba; Aves; Tytonidae) is a raptor widely distributed in the world that also preys prima- 
rily on small mammals (Jaksić et al., 1982; Marti, 1988; Bellocq, 2000) in open areas such as fields (Fast and Ambrose, 1976; Bellocq, 1990, 2000).

White-tailed Kites and Barn Owls are also similar in body size and food requirements (Bozinovic and Medel, 1988). Despite these ecological similarities between them (hunting habitat, food requirements, and specialization in small mammals) and a fundamental difference concerning their hunting activity periods (diurnal for kites and nocturnal for owls), little is known about their food partitioning in the Americas (Jaksić et al., 1981), where they are sympatric in many regions and in a variety of habitats (Jaksić et al., 1981; Jaksić, 1983; Leveau et al., 2002).

One of the most important factors influencing prey frequencies in the diet of many predators is the total time of overlap between the activity period of predators and prey (Jaksić et al., 1981). For predators such as Whitetailed Kites and Barn Owls, which prey on active small mammals, it is expected that the prey consumed are active during the predator's foraging period. Despite this important feature, prey frequencies in the diet of Whitetailed Kites and Barn Owls have been rarely examined simultaneously and discussed in terms of the daily activity period of their prey (Jaksić et al., 1981).

In Brazil, only a few studies have examined the diet composition of Barn Owls in central (Motta-Júnior and Talamoni, 1996; Bonvicino and Bezerra, 2003) and southern Brazil (González et al., 1999; Scheibler and Christoff, 2004), as well as of White-tailed Kites in southern Brazil (Scheibler et al., 2001; Scheibler, 2004).

Small mammal prey partitioning between breeding White-tailed Kites and Barn Owls in an agrarian area of southern Brazil were evaluated. Furthermore, data on relative abundance and daily activity period of their main small mammal prey is provided.

\section{Material and Methods}

\subsection{Study area}

The study area $\left(29^{\circ} 35^{\prime} \mathrm{S}\right.$ and $\left.52^{\circ} 12^{\prime} \mathrm{W}\right)$ was located near Venâncio Aires, Rio Grande do Sul State, southern Brazil. The topography is relatively flat (approximately $50 \mathrm{~m}$ elevation). The climate is subtropical-humid, with a mean annual temperature ranging between 18 and $20{ }^{\circ} \mathrm{C}$. The average annual rainfall of about $1,700 \mathrm{~mm}$ is evenly distributed throughout the year. The original vegetation of deciduous seasonal forests is quite reduced today, having been replaced by agriculture. For more details on relief, climate, and vegetation see Fundação IBGE (1986). The present landscape is a mosaic of vegetation types, prevailing crop fields of annual cultures such as tobacco, bean, and cassava. However, in terms of the total area used, corn crops prevail. Another important vegetation type is locally known as "capoeira", an ungrazed environment mostly consisting of grasses and shrubs of Baccharis spp. It was estimated that crop fields cover $70 \%$ of the study area, followed by "capoeiras" (approximately 20\%). The remaining area consists mainly of small patches of native forest, eucalyptus plantations, small swamps and cattle pasture.

\subsection{Sampling and prey analysis}

In November 1999, remains which were regurgitated by Barn Owls (mainly small mammals) from six nests were collected. These remains were accumulated forming a pile of old fragmented pellets in and around the nests. Invertebrate remains such as insect parts were probably not preserved. Therefore, only osteological remains for Barn Owls were analyzed. It is not known when these remains were regurgitated nor if the six nests correspond to six different years.

For breeding White-tailed Kites, 73 regurgitated pellets between December 1997 and February 1998, 233 between September 1998 and February 1999, 273 between September 1999 and February 2000, and 81 between October 2000 and November 2000 were collected. In Venâncio Aires, it was observed that the breeding season of the White-tailed Kite starts in August-September (egglaying and incubation) lasting up to January-February, when adults interrupted parental care. Pellets were collected under active nests and at roosts near these nests. White-tailed Kites were relatively rare in the study area. In every breeding season, pellets from two pairs were collected; however, the identity of the individuals sampled during the study period is not certain.

Additionally, during October, 200162 pellets of two pairs of breeding White-tailed Kites and 71 of Barn Owls (from one nest) were collected. These individuals of kites and owls were not the ones mentioned above. As there are whole pellets of Barn Owls and because the time in which they were regurgitated for both raptors is known, these data is separate.

The consumed small mammals based on cranial structures were identified, primarily from a morphological pattern of teeth, which were compared with a collection of small mammals captured in the study area and from the mammal collection of the Department of Zoology of the Universidade Federal do Rio Grande do Sul. For Barn Owls, where the sample in question was a mixture of osteological remains belonging to several prey, right and left upper maxillaries (hemimaxillas) of small mammals were identified because the distinction between remains of adults of two rodent species, Akodon paranaensis and Necromys lasiurus, was only possible based on the incisive foramen position, due to the great molar tooth wear. This structure is only found on the upper maxillaries. Mammalian prey specimens such as juveniles and adults were also identified. For rodents, as in Schlatter et al. (1980), the degree of molar tooth wear was used. For marsupials, the size of maxillaries was used because of the low degree of tooth wear presented by adults.

In addition to the proportion of prey taken, the biomass provided by small mammals to the raptors' diet was calculated. Based on the size of the maxillaries examined and using reference specimens collected in the study 
area, the mean body mass of juveniles to be half that of adults was assumed. I obtained body masses of adult N. lasiurus, A. paranaensis, Mus musculus, Oligoryzomys nigripes, and Monodelphis dimidiata from specimens collected in the study area. The body mass of Holochilus brasiliensis was obtained from the mammal collection of the Department of Zoology at the Universidade Federal do Rio Grande do Sul. The body mass of Rattus rattus was obtained from Tamarin and Malecha (1972), and body masses of Cavia aperea and Rattus norvegicus from Silva (1994). Body masses of the bats Molossus molossus and Tadarida brasiliensis were arbitrarily estimated to be the midpoint of the body mass ranges reported by Mares et al. (1989). The overlap of foodniches between the kites and owls using the index described by Pianka (1974) were evaluated which renders values ranging between 0 and 1 (null to complete overlap). Differences in the relative frequency of prey species between the raptors' diet were statistically analyzed by means of G-tests. Differences in the size of small mammals consumed by kites and owls were tested by means of the Mann-Whitney U-test.

\subsection{Daily activity and abundance of mammalian prey}

During January 2002 (Summer), June 2002 (Winter), October 2003 (Spring), and April 2004 (Fall), the daily activity period of small mammals live-trapped in "capoeiras" of the study area were assessed. Grids were set consisting of five lines with 15 traps/line and by a sixth line with six traps (81 traps/grid). Lines and traps were spaced by $10 \mathrm{~m}$. For every season, the grid was operated for six days of capturing, alternating days with and without capturing. Afterwards, the grid was moved to another area where small mammals were live-trapped for three more days. Moving the grid and alternating days with and without capturing prevented the animals from becoming "trap happy", becoming active during atypical periods. Moving the grid also enabled me to sample more individuals. Sampling corresponded to 24 hours of continuous capture, except for the summer, when the hottest hours of the day were avoided because the animals died due to the heat. Traps were checked every 2 hours 45 minutes. For every season, the trap-checking periods were adjusted to coincide with the sunrise and sunset. This enabled me to distinguish periods of diurnal, nocturnal, and crepuscular activity. For the analyses, records of the same individuals captured in a subsequent checking period were disregarded because it was not possible to know if a consecutive record reflected effective activity during this period or if the animal simply entered a trap it found while searching for its shelter. However, most records were not subsequent. A daily activity period is part of a wider study on the community ecology of small mammals in southern Brazil. For the purpose of the study presented here, I compare the proportion between crepuscular (records obtained for the periods of 2 hours 45 minutes after sunset and before sunrise) diurnal, and nocturnal activity.
During October 2001 (Spring) and April 2002 (Fall), information was obtained on relative abundance of small mammals in crop fields and ungrazed sites ("capoeiras") of the study area. For each vegetation type and season, a grid of 133 live-traps was set which operated for six consecutive days. Grids were operated between two hours before sunset and two hours after sunrise. The grid had 19 trap lines spaced $8 \mathrm{~m}$ apart. Lines had seven traps also spaced $8 \mathrm{~m}$ apart. The total capture effort for each vegetation type and season was 798 trap-nights. For both the abundance and activity rhythm study, wire mesh cage traps were used $(10 \times 10 \times 22 \mathrm{~cm})$ baited with a mixture of peanut butter and sardines.

\section{Results}

1,276 prey consumed by the White-tailed Kite and 2,087 by the Barn Owl (Tables 1,2) were identified. Breeding kites and owls presented very similar diets. Pianka's index value was 0.98 . The cosmopolitan rodent $M$. musculus was the main prey of kites and owls both in terms of frequency and biomass provided (Table 1). Owls consumed more M. musculus $\left(\mathrm{G}_{1}=126.5\right.$, $\mathrm{p}<0.0001)$, O. nigripes $\left(\mathrm{G}_{1}=18.3, \mathrm{p}<0.0001\right)$, and $R$ rattus $\left(\mathrm{G}_{1}=17.7, \mathrm{p}<0.0001\right)$; and kites took more M. dimidiata $\left(\mathrm{G}_{1}=145.9, \mathrm{p}<0.0001\right), C$. aperea $\left(\mathrm{G}_{1}=32.8, \mathrm{p}<0.0001\right), \quad$ N. lasiurus $\left(\mathrm{G}_{1}=20.9\right.$, $\mathrm{p}<0.0001)$, A. paranaensis $\left(\mathrm{G}_{1}=26.3\right.$, $\left.\mathrm{p}<0.0001\right)$, and birds $\left(\mathrm{G}_{1}=59.3, \mathrm{p}<0.0001\right)$.

Mammalian prey consumed by owls $(n=1,769)$ were smaller than those taken by kites $(n=996)$ (MannWhitney U-test $=691450.5, \mathrm{p}<0.0001)$. The analysis of the pellets collected during October, 2001 presented similar results to the remaining study (Table 2), indicating that insects and other invertebrates have little importance for the diet of breeding Barn Owls in southern Brazil.

The daily activity period of $M$. musculus, A. paranaensis, and $O$. nigripes was mainly nocturnal/crepuscular; $N$. lasiurus was mainly diurnal/crepuscular, and M. dimidiata was predominantly diurnal (Figure 1). Mus musculus was the most abundant small mammal in crop fields, and the native species were more common in ungrazed areas (Table 3).

\section{Discussion}

Although the White-tailed Kite and Barn Owl differ markedly in their hunting activity periods, they present a high overlap of food-niches during the breeding in the agrarian area of southern Brazil. Based on the daily activity period of their main small mammal prey, a lower overlap would be expected. Differences in the prey frequencies between the diet of owls and kites would be expected for $M$. dimidiata, $N$. lasiurus, and $O$. nigripes. Also for birds, C. aperea, a diurnal rodent (González, 2001), and $R$. rattus, a nocturnal species (Emmons and Feer, 1997). On the other hand, it is interesting that the mainly crepuscular/nocturnal A. paranaensis is taken more often by the diurnal kite. Likewise, the crepuscular/ 
Table 1. Prey in the diet of breeding White-tailed Kites and Barn Owls in Venâncio Aires. $\mathrm{J}=$ juveniles, $\mathrm{A}=$ adults. Figures for small mammals consumed by owls are minimum number of specimens because only right and left upper maxillaries were identified (see details in methods).

\begin{tabular}{|c|c|c|c|c|c|c|c|c|c|c|c|c|}
\hline \multirow{3}{*}{$\begin{array}{c}\begin{array}{c}\text { Prey (adult body mass in } \\
\text { grams) }\end{array} \\
\end{array}$} & \multicolumn{6}{|c|}{ White-tailed Kite } & \multicolumn{6}{|c|}{ Barn Owl } \\
\hline & \multicolumn{3}{|c|}{$\begin{array}{l}\text { Number of } \\
\text { individuals }\end{array}$} & \multicolumn{3}{|c|}{$\begin{array}{c}\text { biomass } \\
\text { supplied }(\%) \\
\end{array}$} & \multicolumn{3}{|c|}{$\begin{array}{l}\text { Number of } \\
\text { individuals }\end{array}$} & \multicolumn{3}{|c|}{$\begin{array}{c}\text { biomass } \\
\text { supplied }(\%) \\
\end{array}$} \\
\hline & $\mathbf{A}$ & $\mathbf{J}$ & Total (\%) & $\mathbf{A}$ & $\mathbf{J}$ & Total & $\mathbf{A}$ & $\mathbf{J}$ & Total (\%) & $\mathbf{A}$ & $\mathbf{J}$ & Total \\
\hline \multicolumn{13}{|l|}{ RODENTIA } \\
\hline $\begin{array}{l}\text { Akodon } \\
\text { paranaensis (42) }\end{array}$ & 47 & 15 & $62(5)$ & 9 & 1 & 10 & 13 & 21 & $34(2)$ & 2 & 1 & 3 \\
\hline Necromys lasiurus (46) & 45 & 44 & $89(8)$ & 9 & 4 & 13 & 36 & 32 & $68(4)$ & 5 & 2 & 7 \\
\hline $\begin{array}{l}\text { Brucepattersonius } \\
\text { iheringi }\end{array}$ & - & 1 & $1(<1)$ & - & - & - & 3 & 1 & $4(<1)$ & - & - & - \\
\hline Calomys sp. & - & - & - & - & - & - & 5 & 1 & $6(<1)$ & - & - & - \\
\hline $\begin{array}{l}\text { Holochilus } \\
\text { brasiliensis (284) }\end{array}$ & - & 1 & $1(<1)$ & - & 1 & 1 & 2 & 12 & $14(1)$ & 2 & 6 & 8 \\
\hline $\begin{array}{l}\text { Oligoryzomys } \\
\text { nigripes (27) }\end{array}$ & 14 & 12 & $26(2)$ & 2 & 1 & 3 & 47 & 49 & $96(5)$ & 4 & 2 & 6 \\
\hline Oryzomys sp. & - & - & - & - & - & - & - & 1 & $1(<1)$ & - & - & - \\
\hline Cavia aperea $(500)^{\mathrm{a}}$ & - & - & $27(2)$ & - & 15 & 15 & - & 3 & $3(<1)$ & - & 1 & 1 \\
\hline Mus musculus (17) & 444 & 289 & $733(63)$ & 33 & 11 & 44 & 771 & 711 & $1,482(81)$ & 43 & 20 & 63 \\
\hline Rattus norvegicus (350) & - & 1 & $1(<1)$ & - & 1 & 1 & - & 1 & $1(<1)$ & - & 1 & 1 \\
\hline Rattus rattus (92) & 2 & 7 & $9(1)$ & 1 & 1 & 2 & 4 & 48 & $52(3)$ & 1 & 7 & 8 \\
\hline Rattus sp. & - & - & $5(<1)$ & - & - & - & - & - & - & - & - & - \\
\hline Unidentified & - & - & $38(3)$ & - & - & - & - & - & $25(1)$ & - & - & - \\
\hline \multicolumn{13}{|l|}{ MARSUPIALIA } \\
\hline $\begin{array}{l}\text { Monodelphis } \\
\text { dimidiata (41) }\end{array}$ & 42 & 33 & $110(9)^{\mathrm{b}}$ & 8 & 3 & 11 & 3 & 9 & $12(1)$ & $<1$ & $<1$ & $<1$ \\
\hline \multicolumn{13}{|l|}{ CHIROPTERA } \\
\hline $\begin{array}{l}\text { Molossus } \\
\text { molossus (12) }\end{array}$ & - & - & - & - & - & - & 1 & - & $1(<1)$ & $<1$ & - & $<1$ \\
\hline $\begin{array}{l}\text { Tadarida } \\
\text { brasiliensis (16) }\end{array}$ & - & - & - & - & - & - & 6 & - & $6(<1)$ & $<1$ & - & $<1$ \\
\hline Unidentified & - & - & - & - & - & - & - & - & $1(<1)$ & - & - & - \\
\hline BIRDS & - & - & $62(5)$ & - & - & - & - & - & $14(1)$ & - & - & - \\
\hline ANURANS & - & - & - & - & - & - & - & - & $2(<1)$ & - & - & - \\
\hline REPTILIA & - & - & $4(<1)$ & - & - & - & - & - & - & - & - & - \\
\hline INSECTA & - & - & $1(<1)$ & - & - & - & - & - & - & - & - & - \\
\hline Total prey & & & 1,169 & & & & & & 1,822 & & & \\
\hline $\begin{array}{l}\text { Mean weight of small } \\
\text { mammal prey } \pm \mathrm{SD}(\mathrm{g})\end{array}$ & & & $22.4 \pm 21.4$ & & & & & & $17.1 \pm 17.7$ & & & \\
\hline
\end{tabular}

${ }^{a}$ Body mass used to estimate the biomass provided was $125 \mathrm{~g}$ because all individuals consumed by both raptors were young; ${ }^{b}$ Includes those individuals not identified into age classes. In this case, the $\%$ of biomass supplied is underestimated.

nocturnal $M$. musculus consists of more than $60 \%$ of the prey consumed by kites. It should not be forgotten that the period of activity defined here as crepuscular corresponds to 2 hours 45 minutes after sunset and before sunrise. Obviously, only part of this is really crepuscular. Suitable daylight for kites at these periods lasts approximately 30 minutes. Thus, mammalian prey at a crepuscular activity such as A. paranaensis and as M. musculus should be more available for the nocturnal Barn Owl than for the diurnal White-tailed Kite. This phenomenon could be accounted for by at least two factors (or a combination of both): 1) high abundance of M. musculus; and 2) differential vulnerability of prey. Mus musculus is the most abundant small mammal in the agrarian area of southern Brazil, occurring in high densities in crop fields, which consist of most of the land cover (approximately $70 \%$ 
Akodon paranaensis

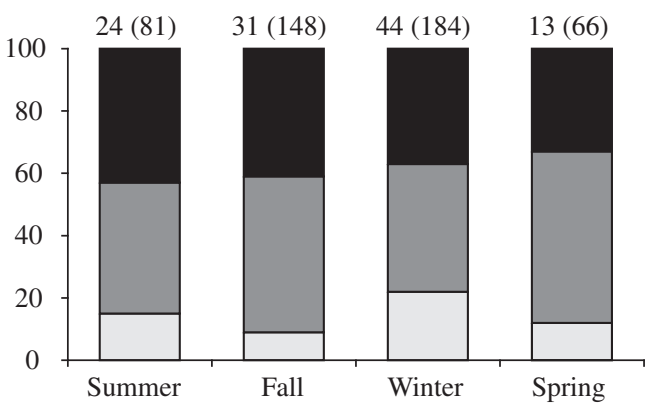

Monodelphis dimidiata

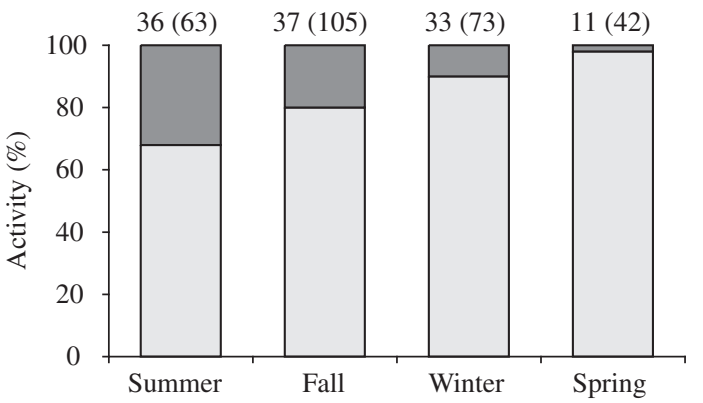

Mus musculus

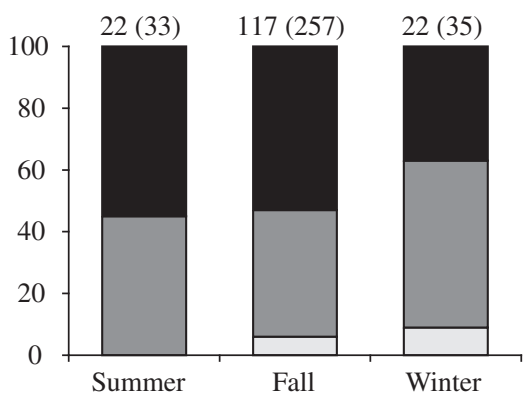

Oligoryzomys nigripes

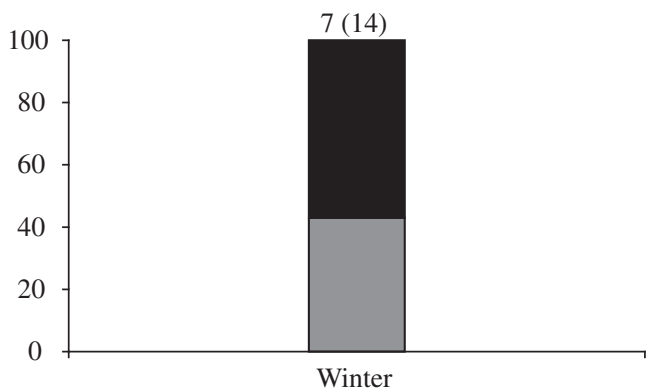

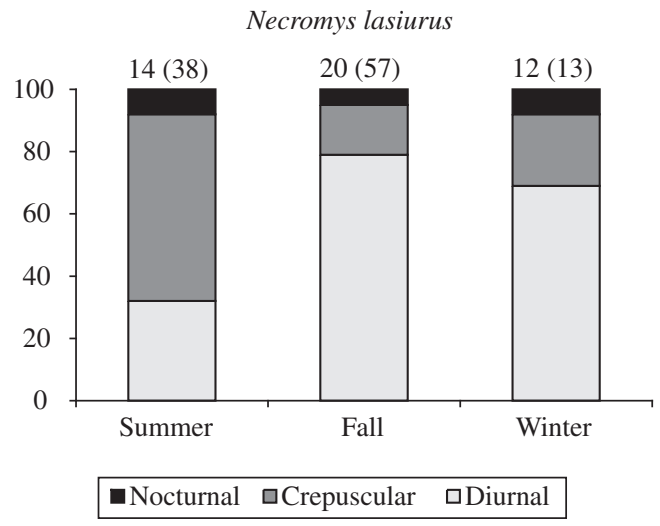

Figure 1. Seasonal daily activity period of small mammals in Venâncio Aires. Values at the top of the columns are number of individuals studied and records (in brackets).

of the study area). Thereby, in spite of its low diurnal activity, M. musculus still could be considerably more abundant than other mammalian prey for the Whitetailed Kite. Concerning the second factor, M. musculus, and also $A$. paranaensis, could be more vulnerable to the predation during the day, as well as at dawn and dusk. It has been demonstrated that White-tailed Kites frequently hunt during the first and last hours of the day (Waian and Stendell, 1970; Warner and Rudd, 1975; Jaksić et al., 1987). In the study area, they were observed hunting after sunset and before sunrise, but there is no information concerning their crepuscular hunting success or which prey are taken at these periods. In central Chile, the White-tailed Kite has been characterized as a crepus- cular predator, as indicated by the activity period of its small mammal prey (Jaksić et al., 1981).

In central Chile, Meserve (1977) suggested that when M. musculus is the primary prey, the White-tailed Kite might not be able to breed successfully since this rodent provides less energy per prey item. In southern Brazil, the contribution of M. musculus in the diet of breeding kites is high; however, lower than for breeding owls. Larger small mammals such as the native species have a higher contribution for the diet of kites. This could be important for their reproduction in southern Brazil because the availability of the small $M$. musculus during the kites' foraging period (remember that M. musculus is mainly crepuscular/nocturnal) could not be highly suf- 
Table 2. Prey in the diet of White-tailed Kites and Barn Owls during October 2001 in Venâncio Aires.

\begin{tabular}{lcc}
\hline \multicolumn{1}{c}{ Prey } & White-tailed kite & Barn owl \\
\cline { 2 - 3 } RODENTIA & Numbers $(\%)$ & Numbers $(\%)$ \\
Akodon paranaensis & $5(5)$ & $6(2)$ \\
Holochilus brasiliensis & - & $2(1)$ \\
Mus musculus & $70(65)$ & $221(83)$ \\
Necromys lasiurus & $3(3)$ & $7(3)$ \\
Oligoryzomys nigripes & $2(2)$ & $9(3)$ \\
Rattus rattus & $2(2)$ & $13(5)$ \\
Unidentified & $6(5)$ & $4(1)$ \\
MARSUPIALIA & & $1(<1)$ \\
Didelphis sp. & - & $1(<1)$ \\
Monodelphis dimidiata & $18(17)$ & $1(<1)$ \\
BIRDS & $1(1)$ & $265(100)$ \\
Total & $107(100)$ & \\
\hline
\end{tabular}

Table 3. Abundance of small mammals in the most common vegetation types of Venâncio Aires. Density = number of individuals per hectare.

\begin{tabular}{|c|c|c|c|c|c|c|c|c|}
\hline \multirow[t]{3}{*}{ Species } & \multicolumn{4}{|c|}{ Spring } & \multicolumn{4}{|c|}{ Fall } \\
\hline & \multicolumn{2}{|c|}{ Crop field } & \multicolumn{2}{|c|}{ Ungrazed area } & \multicolumn{2}{|c|}{ Crop field } & \multicolumn{2}{|c|}{ Ungrazed area } \\
\hline & $\begin{array}{c}\text { Individuals } \\
(\%)\end{array}$ & Density & $\begin{array}{c}\text { Individuals } \\
(\%)\end{array}$ & Density & $\begin{array}{c}\text { Individuals } \\
(\%)\end{array}$ & Density & $\begin{array}{c}\text { Individuals } \\
(\%)\end{array}$ & Density \\
\hline Akodon paranaensis & $7(6)$ & 5.8 & $24(43)$ & 19.8 & $3(5)$ & 2.5 & $38(55)$ & 31.4 \\
\hline Gracilinanus sp. & - & - & $1(2)$ & 0.8 & - & - & - & - \\
\hline $\begin{array}{l}\text { Monodelphis } \\
\text { dimidiata }\end{array}$ & $1(1)$ & 0.8 & $20(36)$ & 16.5 & - & - & $10(14)$ & 8.3 \\
\hline Mus musculus & $99(92)$ & 81.8 & $1(2)$ & 0.8 & $48(90)$ & 39.7 & 13 (19) & 10.7 \\
\hline Necromys lasiurus & - & - & $7(12)$ & 5.8 & $3(5)$ & 2.5 & $8(11)$ & 6.6 \\
\hline $\begin{array}{l}\text { Oligoryzomys } \\
\text { nigripes }\end{array}$ & $1(1)$ & 0.8 & $2(3)$ & 1.6 & - & - & - & - \\
\hline Oxymycterus sp. & - & - & $1(2)$ & 0.8 & - & - & $1(1)$ & 0.8 \\
\hline Total & $108(100)$ & 89.2 & $56(100)$ & 46.1 & $54(100)$ & 44.7 & $70(100)$ & 57.8 \\
\hline
\end{tabular}

ficient to provide the food intake necessary and because larger prey give them a higher energetic reward. Warner and Rudd (1975) found that the proportion of large mammalian prey was higher in the diet of breeding Whitetailed Kites than non-breeding ones in California. In South Africa, Slotow and Perrin (1992) found the same for the closely related species, the Black-shouldered Kite (E. caeruleus). On the other hand, Barn Owls breed successfully in southern Brazil preying heavily on small mammalian prey such as $M$. musculus. The second prey more consumed by owls, $O$. nigripes, is also relatively small (see Table 1 for prey body masses). Certainly, a high nocturnal availability of such "light" prey must be necessary for owls to obtain the food intake sufficient to breed successfully in the agrarian area of southern Brazil.
Acknowledgments - I would like to thank MA. Pizo and A. Zillikens for reviewing a previous version of the manuscript. This work was supported by the Fundação de Amparo à Pesquisa do Estado de São Paulo (FAPESP) (process 01/01917-8)

\section{References}

BELLOCQ, MI., 1990. Composicion y variacion temporal de la dieta de Tyto alba en ecosistemas agrarios pampeanos, Argentina. Vida Silv. Neotrop., vol. 2, p. 32-35.

BELLOCQ, MI., 2000. A review of the trophic ecology of the Barn Owl in Argentina. J. Raptor Res., vol. 34, p. 108-119.

BONVICINO, CR. and BEZERRA, AMR., 2003. Use of regurgitated pellets of Barn Owls (Tyto alba) for inventorying small mammals in the cerrado of central Brazil. Stud. Neotrop. Fauna Environm., vol. 38, p. 1-5. 
BOZINOVIC, F. and MEDEL, RG., 1988. Body size, energetic and foraging mode of raptors in central Chile. Oecologia, vol. 75 , p. 456-458.

DUNK, JR., 1995. White-tailed Kite (Elanus leucurus). In: A. Poole and F. Gill (eds.), The birds of North America. The Academy of Natural Sciences, Philadelphia and The American Ornithologists' Union, Washington, DC, p. 1-15.

EMMONS, LH. and FEER, F., 1997, Neotropical Rainforest Mammals: A Field Guide (2nd ed.). University of Chicago Press, Chicago, 307p.

FAST, SJ. and AMBROSE, HW., 1976. Prey preference and hunting habitat selection in the Barn Owl. Am. Midl. Nat., vol. 96 , p. 503-507.

FUNDAÇÃO IBGE., 1986. Levantamento de Recursos Naturais, folha SH.22 Porto Alegre e parte das folhas SH.21 Uruguaiana e SI.22 Lagoa Mirim. Fundação IBGE, Rio de Janeiro, 791p.

GONZÁLEZ, EM., 2001. Guía de campo de los mamíferos de Uruguay. Introducción al estudio de los mamíferos. Vida Silvestre, Montevideo, 339p.

GONZÁLEZ, EM., CLARAMUNT, SJ. and SARALEGUI, A. M., 1999. Mamíferos hallados en egagrópilas de Tyto alba (Aves, Strigiformes, Tytonidae) en Bagé, Rio Grande do Sul, Brasil. Iheringia Ser. Zool., vol. 86, p. 117-120.

JAKSI, FM., 1983. The trophic structure of sympatric assemblages of diurnal and nocturnal birds of prey. Am. Midl. Nat., vol. 109, 152-162.

JAKSI, FM., GREENE, HW. and YÁÑEZ, JL., 1981. The guild structure of a community of predatory vertebrates in central Chile. Oecologia, vol. 49, p. 21-28.

JAKSI, FM., SEIB, RL. and HERRERA, CM., 1982. Predation by the Barn Owl (Tyto alba) in mediterranean habitats of Chile, Spain and California: A comparative approach. Am. Midl. Nat., vol. 107, p. 151-162.

JAKSI, FM., ROZZI, R., LABRA, A. and JIMÉNEZ, J. E., 1987. The hunting behavior of Black-shouldered Kites (Elanus caeruleus leucurus) in central Chile. Condor, vol. 89, p. 907-911.

LEVEAU, LM., LEVEAU, CM. and PARDIÑAS, UFJ., 2002. Dieta del Milano Blanco (Elanus leucurus) en Argentina. Ornitol. Neotrop., vol. 13, p. 307-311.

MARES, MA., OJEDA, RA. and BARQUEZ, RM., 1989. Guide of the mammals of Salta Province, Argentina. University of Oklahoma Press, Oklahoma, 303p.
MARTI, CD., 1988. A long-term study of food-niche dynamics in the Common Barn-Owl: comparisons within and between populations. Can. J. Zool., vol. 66, p. 1803-1812.

MENDELSOHN, JM. and JAKSI, FM., 1989. Hunting behaviour of Blackshouldered Kites in the Americas, Europe, Africa and Australia. Ostrich, vol. 60, p. 1-12.

MESERVE, PL., 1977. Food habits of a White-tailed Kite population in central Chile. Condor, vol. 79, p. 263-265.

MOTTA-JÚNIOR, JC. and TALAMONI, SA., 1996. Biomassa de presas consumidas por Tyto alba (Strigiformes: Tytonidae) durante a estação reprodutiva no Distrito Federal. Ararajuba vol. 4, p. 38-41.

PIANKA, ER., 1974. Niche overlap and diffuse competition. Proc. Natl. Acad. Sci. USA, vol. 71, p. 2141-2145.

SCHEIBLER, DR., 2004. Geographic variation in the size of mammalian prey taken by White-tailed Kites in the Americas. J. Field Ornithol., vol. 75, p. 218-222.

SCHEIBLER, DR. and CHRISTOFF, AU., 2004. Small mammals in the diet of Barn Owls (Tyto alba) in agroecosystems of southern Brazil. Ornitol. Neotrop., vol. 15, p. 65-70.

SCHEIBLER, DR., MENEGHETI, JO. and CHRISTOFF, AU., 2001. Predação de Elanus leucurus (Aves, Accipitridae) sobre Mus musculus (Mammalia, Muridae) e sua variação no tempo, em agroecossistema de Venâncio Aires, Rio Grande do Sul, Brasil. Bol. Soc. Biol. Concepción, vol. 72, p. 125-130.

SCHLATTER, RP., TORO, B., YÁÑEZ, JL. and JAKSI, FM., 1980. Prey of the White-tailed kite in central Chile and its relation to the hunting habitat. Auk, vol. 97, p. 186-190.

SILVA, F., 1994. Mamíferos Silvestres - Rio Grande do Sul ( $2^{\mathrm{a}}$ ed.). Fundação Zoobotânica do Rio Grande do Sul, Porto Alegre, 246p.

SLOTOW, R. and PERRIN, M. R., 1992. The importance of large prey for Blackshouldered Kite reproduction. Ostrich, vol. 63, p. 47-52.

TAMARIN, RH. and MALECHA, SR., 1972. Reproductive parameters in Rattus rattus and Rattus exulans of Hawaii, 1968 to 1970. J. Mammal., vol. 53, p. 513-528.

WAIAN, LB. and STENDELL, RC., 1970. The White-tailed Kite in California with observations of the Santa Barbara population. Cal. Fish Game, vol. 56, p. 188-198.

WARNER, JS. and RUDD, RL., 1975. Hunting by the Whitetailed Kite (Elanus leucurus). Condor, vol. 77, p. 226-230. 